\title{
Can industrial cleaning procedures make Urochloa ruziziensis seeds nematode free?
}

\author{
Rita de Cássia Lima Mazzuchelli, Ceci Castilho Custódio, Nelson Barbosa Machado Neto, Fábio \\ Fernando de Araújo*
}

\author{
Agricultural Sciences College at UNOESTE, Presidente Prudente, SP, CEP 19067175, Brazil
}

\section{*Corresponding author: fabio@unoeste.br}

\begin{abstract}
Seeds for agriculture should be pathogens free e.g. from plant-parasitic nematodes that if present in seed lots may be transferred to other clean areas as inoculum to infest other host plants. The aim of this work was to identify and quantify active forms of nematodes during the cleaning procedures of Urochloa ruziziensis seeds and also to evaluate its efficiency in turning the seeds nematodes free. Three seed lots with distinct origins were used. They were sampled four times in different parts of the process such as the reception and during the cleaning procedures consisting of the following treatments: unclean seeds, after using air screen cleaner, after using gravity separator (clean seeds) and the dust particles (seed covers and empty seeds). Identification and quantification of nematodes were done in each of the samples. The results showed that there is reduction in active number of Aphelenchoides and Ditylenchus nemaodes after cleaning procedures of seeds. However, this reduction does not meet the standards to be disseminated as pathogen free seeds for commercialization. The active Meloidogyne form was found only in one seed lot, but the cleaning procedures was effective to eliminate the parasites from the clean commercial seed. Others control forms need to be introduced into the system to turn pasture seed free of nematodes.
\end{abstract}

Keywords: Brachiaria, pasture, Aphelenchoides, Ditylenchus, Meloidogyne.

\section{Introduction}

The seed production of tropical pastures increased in the past decade to attend the world's demand, contributing to cattle food security, which guarantees their nutrition, principally in tropical zones. The tropical pastures are considered as a healthy and low-cost diet for cattles (Rudel et al., 2015). On the other hand, the use of Urochloa ruziziensis, as a component in the integrated crop-livestock and direct sowing systems is being increasing because it produces a large amount of dry mass ( $27 \mathrm{t} \mathrm{ha}^{-1}$ in average), and could be easily eradicated by herbicides. It has a decumbent growth and covers the soil surface with abundant leaves, culms and thin roots, which is an effective contribution to the physic restoration of the soil structure (Marochi et al., 2005).

However, the pasture seed production can be threatened by the presence of phytopathogens and also by the absence of sanity standards for seed commercialization. In this context, seeds maybe a disseminating system for many pathogens and pests, which can affect the main culture in an integrated croplivestock system, from plant establishment to harvesting (Marchi et al., 2007).

Nematodes are hard to control and can easily hide in seed lots. This can have direct impacts on productivity, forage growth; seed production and natural pasture recover (Favoreto et al., 2010). The best way of control is prevention form introduction into new clean areas, as there is no effective way to eradicate nematodes. Only its populations can be decreased (Coltro-Roncato et al., 2015).

The phytonematodes cause a major obstacle to seed pasture exports, as seed importers may impose phytosanitary restrictions on seeds (Marchi et al., 2007). For pasture seeds, the harvest might be directly from plants, avoiding the soil sweeping process (Mallmann et al., 2013; Alves et al., 2017). Favoreto et al. (2010) pointed out that control of nematodes in pasture seeds can prevent dissemination, especially considering integrated crop-livestock system and the loss of pasture yield to livestock. Seed infection by nematodes may occur by the contact of the seed with the soil. Most Urochloa seeds are harvested from sweeping from the ground, where the fallen seeds could be collected from the surface and mechanically removed with soil particles which, in turn, may contain nematodes (Coelho et al., 2006).

In Brazil, Aphelenchoides species, especially A. besseyi, and some Ditylenchus are found in forage seeds (Favoreto et al., 2006). The Aphelenchoides and Ditylenchus are also pathogens of sugarcane crop, arising major concern since forage areas are being replaced by sugarcane (Tokeshi and Rago, 2005).

Favoreto et al. (2006) found that cleaning procedures in $U$. brizantha seed removed more Ditylenchus species than Aphelenchoides, since Ditylenchus are found in larger dust particles, which are easily removed during the process. A. besseyi is the causal agent nematode of rice "white tip" and can survive up to 19 years inside the seeds (Bedendo and Prabhu, 2005). The A. besseyi dissemination is mainly occurred by infested seeds; therefore, identification and elimination methods of these nematodes is necessary (Bueno et al., 2002).

Meloidogyne incognita is considered as very harmful nematode to plants and found in more than 2000 plant species inducing the lateral root knot gall. The gall causes a reduction in plant development, even in very low populations (Asmus and Inomoto, 2007).

The Meloidogyne genus was less frequently associated with pasture seeds but they are not less harmful if not removed. It can be disseminated by seeds to other areas and present a great potential problem, since it has associations with many crops reducing their growth and yields (Zambiasi et al., 2007). 
Table 1. Active forms of Aphelenchoides, Ditylenchus and Meloidogyne nematodes in three unclean seeds lots of Urochloa ruziziensis.

\begin{tabular}{lccc}
\hline Lot & Aphelenchoides spp & Ditylenchus spp & Meloidogyne spp \\
\hline 1 & $1320.8 \mathrm{c}$ & $1483.3 \mathrm{~b}$ & $87.9 \mathrm{a}$ \\
2 & $1691.6 \mathrm{~b}$ & $1620.8 \mathrm{~b}$ & - \\
3 & $3054.1 \mathrm{a}$ & $3645.8 \mathrm{a}$ & - \\
\hline Means followed by different letter, on column, statistically differ by Tukey's test (p<0.01). &
\end{tabular}

Table 2. Active forms of Aphelenchoides, Ditylenchus and Meloidogyne nematodes on Urochloa ruziziensis seeds collected in three steps during industrial seed cleaning procedures, from three seed lots.

\begin{tabular}{|c|c|c|c|}
\hline \multicolumn{4}{|c|}{ Aphelenchoides spp } \\
\hline Lot & Unclean & After air screen cleaner & Clean seeds \\
\hline 1 & $1266.6 \mathrm{cA}$ & $983.3 \mathrm{cAB}$ & $866.6 \mathrm{bB}$ \\
\hline 2 & $1866.6 \mathrm{bA}$ & $1483.3 \mathrm{bB}$ & $1016.6 \mathrm{bC}$ \\
\hline 3 & $3800.0 \mathrm{aA}$ & $2866.6 \mathrm{aB}$ & $1516.6 \mathrm{aC}$ \\
\hline Mean & $2000.0 \mathrm{a}$ & $2088.8 \mathrm{a}$ & $1133.3 \mathrm{~b}$ \\
\hline \multicolumn{4}{|c|}{ Ditylenchus spp } \\
\hline 1 & $1516.6 \mathrm{bA}$ & $1166.6 \mathrm{bB}$ & $550.0 \mathrm{cC}$ \\
\hline 2 & $1300.0 \mathrm{bA}$ & $1316.6 \mathrm{bA}$ & $1133.3 \mathrm{bA}$ \\
\hline 3 & $4350.0 \mathrm{aA}$ & $4583.3 \mathrm{aA}$ & $1816.6 \mathrm{aB}$ \\
\hline Mean & $2388.8 \mathrm{a}$ & $2355.5 \mathrm{a}$ & $1166.6 \mathrm{~b}$ \\
\hline \multicolumn{4}{|c|}{ Meloidogyne spp } \\
\hline 1 & $183.3 \mathrm{aA}$ & $100.0 \mathrm{aB}$ & - \\
\hline 2 & - & - & - \\
\hline 3 & - & - & - \\
\hline Mean & $61.7 \mathrm{a}$ & $34.0 \mathrm{a}$ & - \\
\hline
\end{tabular}

Table 3. Active forms of Aphelenchoides, Ditylenchus and Meloidogyne nematodes on dust particles of Urochloa ruziziensis after cleaning procedures in three seed lots.

\begin{tabular}{lccc}
\hline \multicolumn{1}{c}{ Aphelenchoides spp } & Ditylenchus spp & \\
\hline Lot & & & \\
\hline 1 & $2166.6 \mathrm{~b}$ & $2700.0 \mathrm{~b}$ & \\
2 & $2400.0 \mathrm{~b}$ & $2733.3 \mathrm{~b}$ & $67.3 \mathrm{a}$ \\
3 & $4033.3 \mathrm{a}$ & $3833.3 \mathrm{a}$ & - \\
\hline \multicolumn{2}{l}{ Means followed by different letter, on column, statistically differ by Tukey's test $(\mathrm{p}<0.01)}$. & & - \\
\hline
\end{tabular}

The aim of this work was to identify and to quantify active nematodes forms in unclean, after using air screen cleaner, using gravity separator (clean seeds) and in the dust particles (seed covers and empty seeds). We also verified the efficiency of the industrial procedures in lots of $U$. ruziziensis seeds to make the seeds nematodes free.

\section{Results and Discussion}

All evaluated lots showed positive to Aphelenchoides and Ditylenchus presence. However, the highest concentration of these genera was found in lot 3 . The lot 1 showed the lowest Aphelenchoides and Ditylenchus populations. Nevertheless, in this lot Meloidogyne presence was detected (Table 1).

The seed industrial cleaning procedures decreased the active forms of Aphelenchoides and Ditylenchus although it did not eliminate them. The Aphelenchoides and Ditylenchus infestation did not differ between unclean seeds and after the air screen clean. However, Meloidogyne active forms were eliminated during cleaning procedures of lot 1 (Table 2). Monteiro et al. (2014) studying seed nematodes in Urochloa brizantha, suggested that the internal localization between the coat and endosperm was the reason that seed nematodes are not eradicated, making control and its evaluation difficult. Aphelenchoides was reduced in $U$. ruziziensis seeds after cleaning procedures, but some active forms were detected in the clean seed (commercial ones) (Table 2). In relation to Ditylenchus active forms, there was significant reduction of seed pathogen after process cleaning in two lots. The lot 3 showed the highest nematodes amount of this genus (Table 2). The Meloidogyne active forms were detected only in lot 1 and the amount was lower than detected to others nematodes forms. Meloidogyne is characterized for nematodes that lied in the soils and in roots of susceptible plants (Curto et al., 2005). The penetration in seeds may be superficial as it was observed that the cleaning procedures eliminated those nematodes from seeds at the end of the process, indicating that those nematodes was located in seed external layers, turning the processes more effective (Table 2).

The higher concentration of nematode active forms occurred in dust particles (seed covers and empty seeds) (Table 3). Favoreto et al. (2006) observed that nematodes population differed in cleaning procedures steps and dust particles also exhibited the highest nematodes populations.

The Aphelenchoides and Ditylenchus in analysed lots were associated to $U$. ruziziensis seeds (Marchi et al., 2007). This can be a problem not only to pastures and livestock but also to crops because those are not specific and can be parasites to other crops (Tokeshi and Rago, 2005). The cleaning procedures partially decreased seed parasites showing that commercial seed can still disseminate nematodes to free areas.

An effort to prevent the use of low quality pasture seed per $s e$ is necessary as the seed are being used not only for cattle farmers, but in integrated crop-livestock system, compromising the livestock sustainability and extending it to crops low yielding (Mallmann et al., 2013). Besides the seed industrial cleaning procedures, associations with other 
methods must be implemented to guarantee that pasture seeds are nematode free. In $U$. brizantha seeds, the use of dry heat ( $\left.40-57^{\circ} \mathrm{C}\right)$, prevented the $A$. bessey dissemination into free areas (Tenente et al., 2006). Methods like this, or biological or chemical options, may be studied and adopted as control methods to eliminate nematodes from pasture seeds during seed processing and to protect free areas. Seed nematodes analysis as a routine test must be inserted along with appropriated phytosanitary legislation.

\section{Materials and Methods}

\section{Seed material}

Three seed lots of $U$. ruziziensis were used and sub samples of each were taken during the cleaning procedures by the following steps: after using air screen cleaner, after gravity separator (clean seeds) and dust particles (seed covers and empty seeds). Three repetitions per seed lot and for each step were collected.

\section{Nematode extraction and analysis}

The nematode extraction method followed Coolens and D'Herde (1972) as follows: $20 \mathrm{~g}$ sample was crushed in a blender with $300 \mathrm{~mL}$ distilled water during 30 seconds. The supernatant was passed by 400 mesh screen and the retained material collected was washed with the aid of a water flux from a washing bottle to an $80 \mathrm{~mL}$ Becker. The solution was transferred to $20 \mathrm{~mL}$ centrifuge tube with the addition of 1 $\mathrm{cm}^{3}$ of kaolin. After homogenization, it was centrifuged at $2000 \mathrm{rpm}$ for four minutes. The supernatant was discarded and the tube completed with $45 \%$ sucrose solution. The result solution was homogenized and centrifuged at $2000 \mathrm{rpm}$ for one minute. The supernatant was dropped in 400 mesh screen and the retained material collected was washed with the aid of a water flux from a washing bottle to an $80 \mathrm{~mL}$ Becker. One $\mathrm{mL}$ of sample was transferred to Peters camera to identify the nematode genera and to count the number of each under optical microscope.

\section{Statistical design}

The research was designed as a completely random experiment and the treatments distributed as a factorial array (three seed lots with four distinct cleaning steps) with three repetitions each. The data was submitted to ANOVA using the SISVAR software (Ferreira, 2014) and when significant to the Tukey's test $(\mathrm{p}<0.01)$.

\section{Conclusion}

There was reduction of the active number of Aphelenchoides spp. and Ditylenchus spp. after cleaning procedures of $U$. ruziziensis seeds. However, this did not mean seeds free of parasites for commercialization. Meloidogyne spp. active forms were found only in one seed lot, but the cleaning procedures were effective to eliminate the parasites from it. Others control forms need to be introduced into the system to turn pasture seed nematodes free.

\section{Acknowledgements}

We would like to thanks to UNOESTE and to SOESP (Sementes do Oeste Paulista) for supporting this research and to CAPES for the scholarship to RCLM.

\section{References}

Alves BA, Medeiros LT, Sales FJ, Branquinho AC, Silva JW, Souza RG (2017) Germinação de sementes de forrageiras do gênero Brachiaria em função dos ambientes e tempos de armazenamento. Global Sci and Technol. 10:11-19.

Asmus GL, Inomoto MM (2007) Manejo de nematoides. In: Freire, E.C (ed.). Algodão no cerrado do Brasil. Associação Brasileira dos Produtores de Algodão: Brasília. p.551-580.

Bedendo IP, Prabhu AS (2005) Doenças do arroz. In: Kimati H, Amorim L, Rezende JAM, Bergamin Filho A, Camargo LEA (ed.) Manual de Fitopatologia. 4 ed. São Paulo: Agronômica Ceres. p.79-90.

Bueno ERV, Prates M, Tenente RCV (2002) Avaliação de métodos tradicionais de extração de nematóides aplicados às sementes de Panicum maximum infestadas por Aphelenchoides besseyi. Nematol Bras. 26:213-217.

Coelho MH, Andrade RP, Carmona R, França LV (2006) Avaliação e caracterização de acessos de Stylosanthes guianensis quanto à produção de sementes. Pasturas Tropicales. 28:3-14.

Coolen WA, D'Herde CJ (1972) A method for the quantitative extraction of nematodes from plant tissue. Ministry of Agriculture of Belgium Ghent: Nematology and Entomology Research Station $77 \mathrm{p}$.

Coltro-Roncato S, Gonçalves, EDV, Dildey ODF, Kuhn OJ, Stangarlin JR (2015) Fitoquímicos como controle alternativo de nematoides. In: Kuhn, OJ; Nunes, RV; Stangarlin, JR; Rampi ML (ed). Ciências Agrárias: Tecnologias e Perspectivas. UNIOESTE: Marechal Cândido Rondon, p.188-206.

Curto G, Dallavalle E, Lazzeri L (2005) Life cycle duration of Meloidogyne incognita and host status of Brassicaceae and Capparaceae selected for glucosinate content. Nematol. 7:203-212.

Favoreto L, Santos JM, Calzavara AS, Barbosa JC, Lara LA (2010) Estudo do processo de infecção de sementes de Brachiaria brizantha por espécies de Aphelenchoides e de tratamentos para o controle desses nematoides. Nematol Bras. 34:10-17.

Favoreto L, Santos JM, Barbosa JC, Calzavara AS (2006) Fitonematóides extraídos dos resíduos das fases do beneficiamento e de sementes de Brachiaria brizantha. Nematol Bras. 30:203-209.

Ferreira DF (2014) Sisvar: a guide for its bootstrap procedures in multiple comparisons. Ciênc e Agrotecnol. 38: 109-112.

Mallmann G, Verzignassi JR, Fernandes CD, Santos JMD, Vechiato MH, Inácio CA, Queiroz CDA (2013) Fungos e nematoides associados a sementes de forrageiras tropicais. Summa Phytopathol. 39:201-203.

Marchi CE, Fernandes CD, Borges CT, Santos JM, Jerba, FV, Trentin RA, Araújo LRG (2007) Nematofauna fitopatogênica de sementes comerciais de forrageiras tropicais. Pesqui Agropecu Bras. 42:655-660.

Marochi AI, Borges JH, Scalea M (2005) Brachiaria ruziziensis é alternativa de cobertura de solo para o sistema de plantio direto no cerrado. Agricultura e Meio Ambiente. $3^{\mathrm{a}}$ ed, I.

Monteiro TSA, Nasu, ÉDGC, Guimarães CP, Neves WS, Freitas LG (2014) Redução de inóculo de Aphelenchoides besseyi em sementes de Brachiaria brizantha tratadas com óleos essenciais. Ciênc Rural. 44:1149-1154

Rudel TK, Paul B, White D, Rao IM, Van Der Hoek R, Castro A, Peters M (2015) Livestock plus: Forages, sustainable intensification, and food security in the tropics. Ambio. 44: 685693.

Tenente RC, Sousa AI, Gomes VF, Rodrigues Junior AJ (2006) Techniques to eradicate Aphelenchoides besseyi Christie (1942) from infested Brachiaria brizantha seeds. Nematol Bras. 30:239244.

Tokeshi H, Rago E (2005) Doenças cana-de-açúcar. In: Kimati H, Amorim L, Rezende JAM, Bergamin Filho A, Camargo LEA (ed.) Manual de Fitopatologia. São Paulo: Ceres. p.183-196.

Zambiasi TC, Belot JL, Fuhrmann E, Floriani G, Ghisleni I, Baggio J, Souza VD (2007) Identificação de nematóides fitoparasitas predominantes no Estado do Mato Grosso, na cultura do algodoeiro. In :Congresso Brasileiro de Algodão (Vol. 6). 